\title{
Facies interpretation from well logs applied to the Tertiary Lower Rhine Basin fill
}

\author{
M. Klett ${ }^{1}$, F. Eichhorst ${ }^{1} \&$ A. Schäfer ${ }^{1,2}$ \\ 1 Institute of Geology, University of Bonn, Nussallee 8, 53115 Bonn, Germany; \\ e-mails: michael.klett@cycos.com; eichhorst@shw.com; schaefer@uni-bonn.de \\ 2 Corresponding author
}

Manuscript received: December 2000; accepted: January 2002

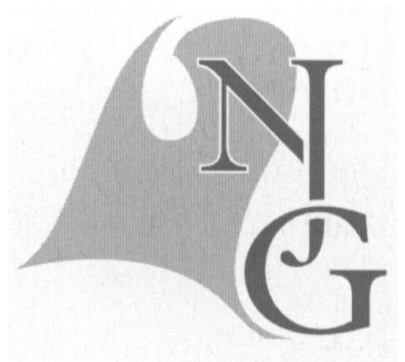

\begin{abstract}
The Cenozoic fill of the Lower Rhine Basin is investigated with data from industry wells and open-cast mines on lignite coal. The geophysical logs of digitised well data are used to calculate lithofacies logs with a newly developed technique. The lithofacies logs allow the interpretation of shallow marine and continental environments in a sequence stratigraphic approach. In addition, base level analysis with both the lithofacies logs and the geophysical logs provide a stratigraphical frame for environment interpretation, modelling, and simulation.
\end{abstract}

Keywords: basin analysis, interpretation of depositional environments, well logs, modelling

\section{Introduction}

Traditional outcrop work and subsurface data from industry provide a rich source for stratigraphical, structural, and environmental interpretations in sedimentary basins. For use under the scope of modern data management, analogue data preferably have to be transformed to digital data. These then allow the introduction to computerized graphical tools, to modelling, and to time-relevant simulation techniques, which form the base for modern basin analysis. This is actually being performed in the Cenozoic Lower Rhine Basin, where the basin configuration, the sediment input to it, and its sedimentology are considered in this study. Stratigraphical, paleoecological, and climatological aspects are worked out by Mörs et al. (in prep.), Mörs (2002), Heuman \& Litt (2002) and Utescher et al. (2002), sedimentological studies were provided by Schäfer et al. (1996; 1997), and structural models are being developed by Jentzsch \& Siehl (2002) and Thomsen \& Siehl (2002). These - and many more in this volume and in previous studies contribute to the understanding of rift basins.

\section{Field of Study}

At the south-eastern end of the Cenozoic Dutch-German rift structure, the Lower Rhine Basin (Fig. 1) forms an asymmetrical graben system - underneath the Lower Rhine Embayment extending about 100 $\mathrm{km}$ in length and $50 \mathrm{~km}$ in width. It subsided along NW-SE oriented faults, which cut into the northwestern margin of the Rhenish Massif (Schäfer, 1994; Schäfer et al., 1997).

Within the Lower Rhine Basin (Fig. 2), from W to E, the Feldbiss, Rur, and Erft faults separate individual eastward dipping tectonic blocks, the Rur, Erft, and Köln blocks in the $S$ of the basin. In the $N$, the Krefeld and Venlo blocks display the eastern upthrown block, whereas the Peel Block in the Netherlands is the downthrown block. The subsidence of those blocks was remarkably heterogeneous; e.g. the 


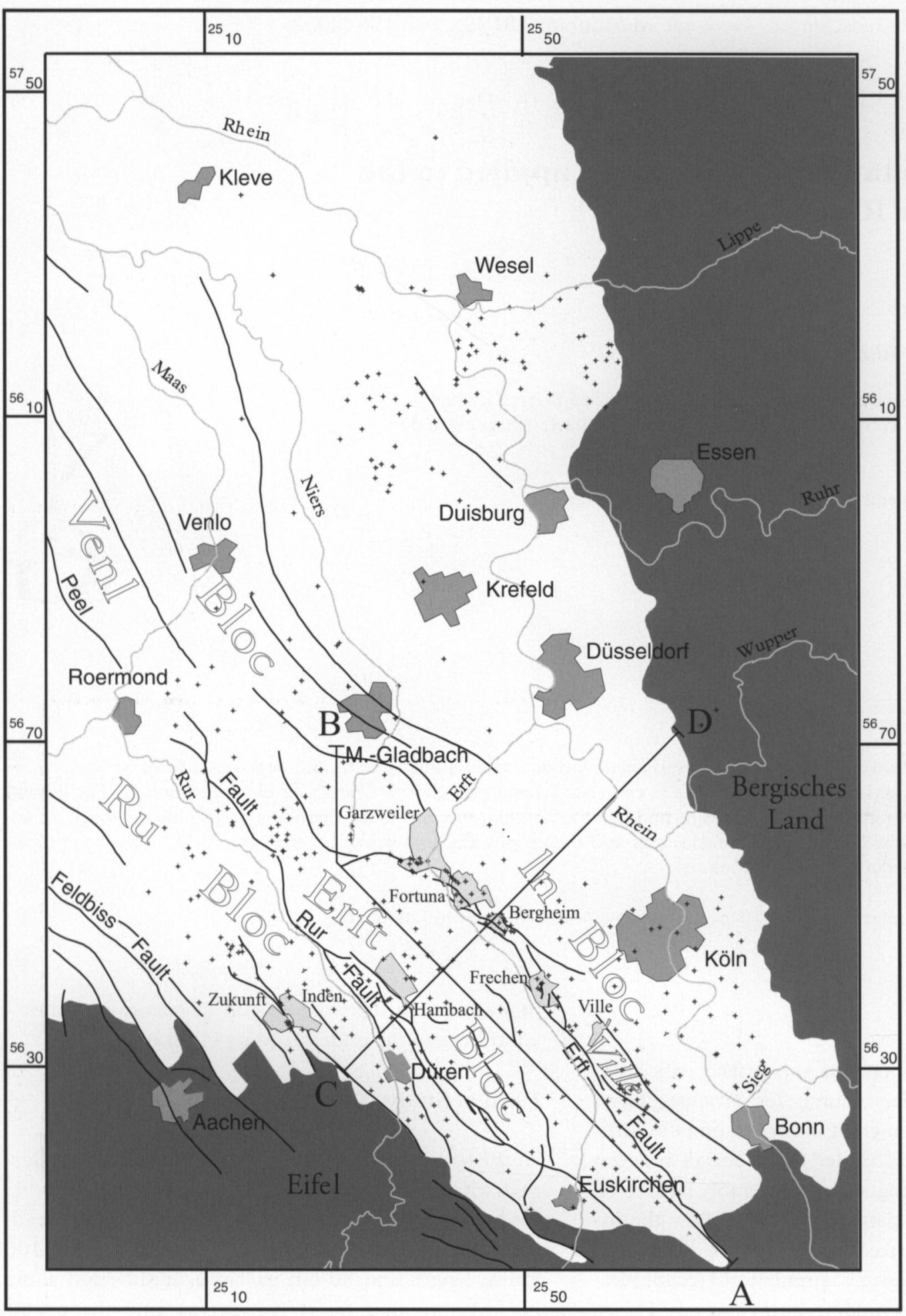

Fig. 1. The Lower-Rhine Embayment (white) is cut into the north-western margin of the Rhenish Massif (dark grey). The subsurface of the embayment is locally exposed by lignite open-cast mines (light grey) and by wells (crosses) of the local lignite mining industry (Rheinbraun AG) and the water industry (Erftverband). The lines A-B and C-D indicate sections discussed in Fig. 2. The names of the tectonic blocks and the faults are shown; the position of the Peel Block is given in Fig. 3.

central Erft Block subsided $1300 \mathrm{~m}$ and the Peel Block in the Netherlands $2000 \mathrm{~m}$ (Fig. 3).

The entire rift structure, from $\mathrm{N}$ to $\mathrm{S}$, unconformably rests on Triassic, Permian, Carboniferous, and Devonian basement.
Still unconsolidated Eocene sediments are only found in some places outside the basin as e.g. in the Graben of Antweiler (in the S of Euskirchen; cf. Fig. 1); its sediments were deposited under a structural regime, which was different from the later rifting peri- 


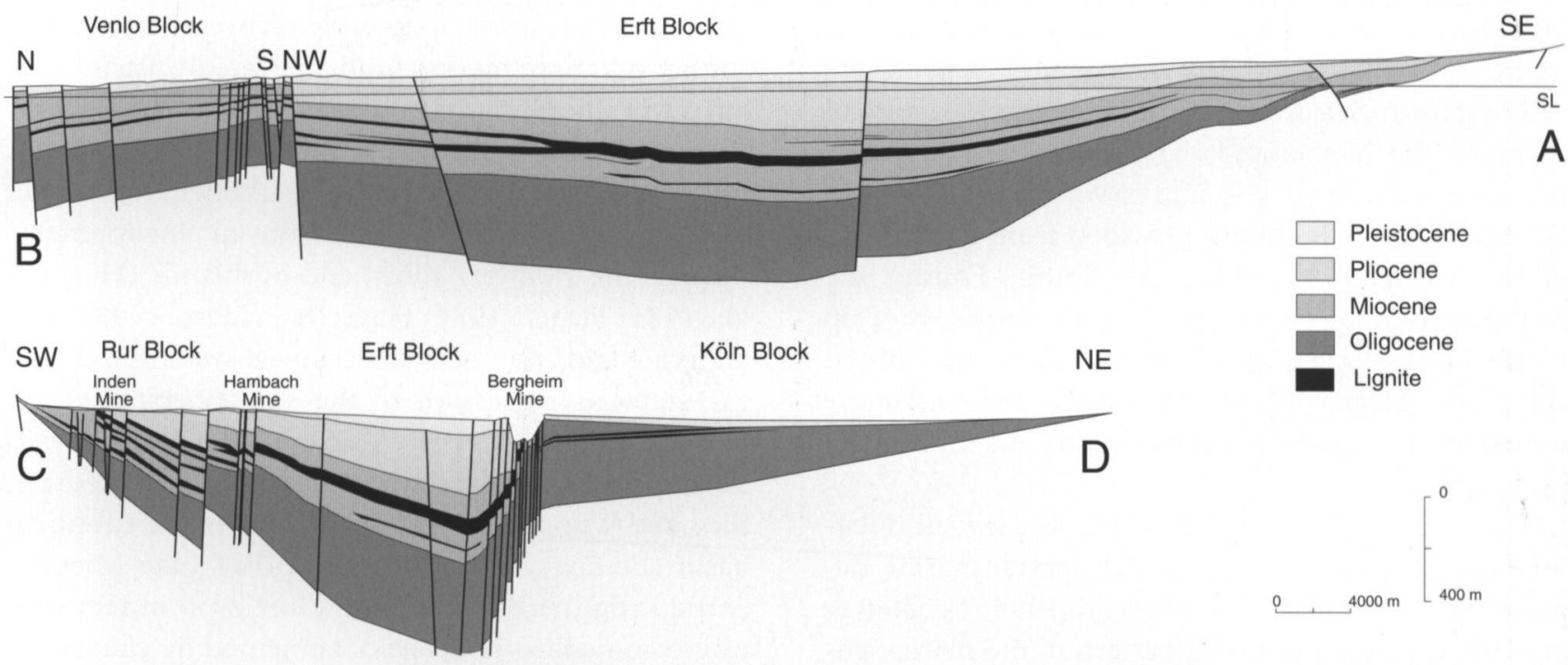

Fig. 2. Sections running SW-NE (C-D in Fig. 1) and SE-NW (A-B in Fig. 1), with tentative Cenozoic stratigraphy. In the SW-NE section, the open-cast mines are marked (the Hambach and Inden mines are projected on the section).

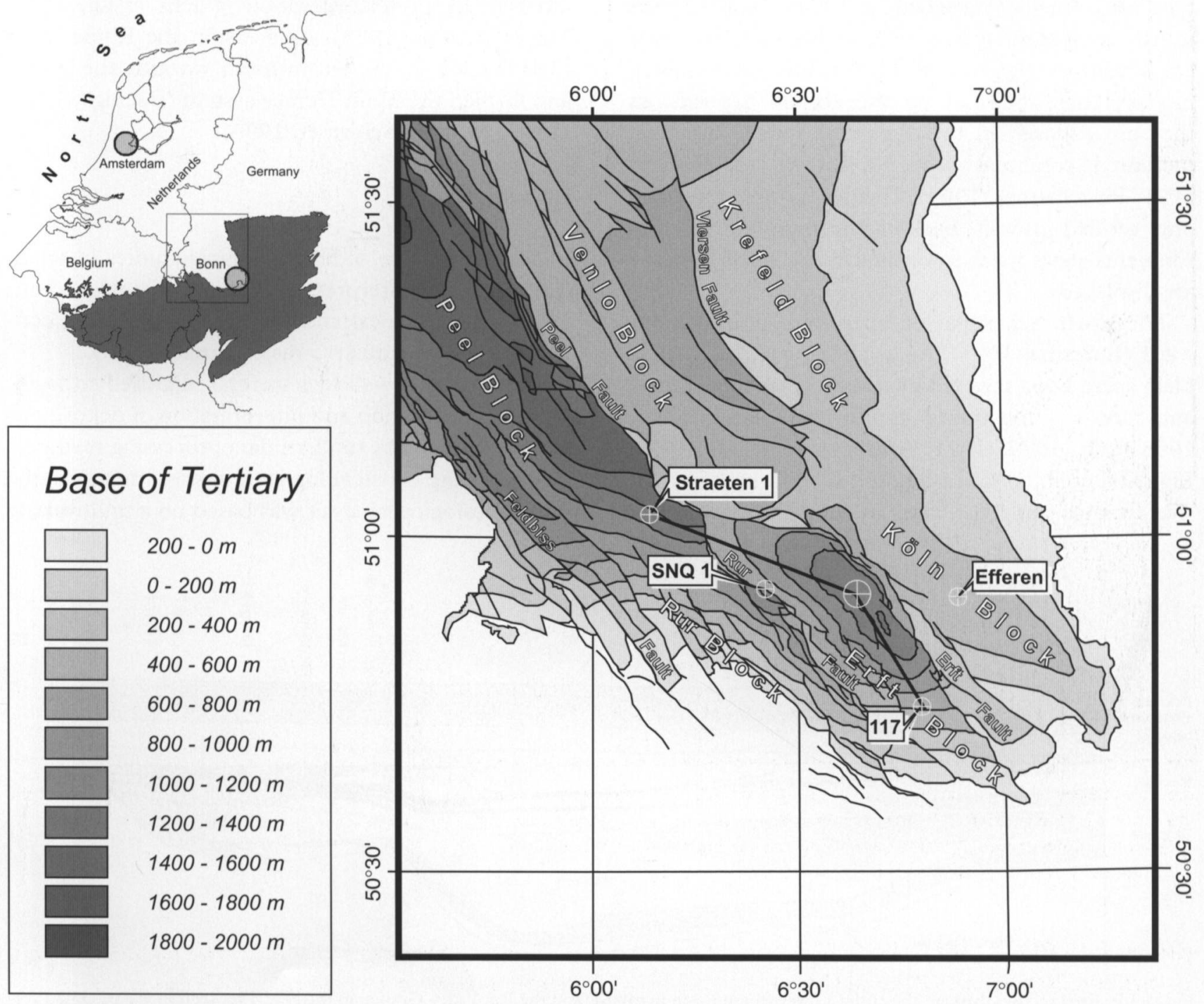

Fig. 3. The Lower-Rhine Basin developed at the NW margin of the Schiefergebirge due to subsidence along NW-SE trending deep-reaching faults. The base of the Tertiary beds specifies the structural contour of the basin and its tectonic blocks (after: Atlas van Nederland, 1985, Deel 13: Geologie, fig. 44; Hager \& Prüfert, 1988, fig. 12). Three wells are indicated, connecting a profile section, shown in Fig. 8. 
od of the Lower Rhine Basin. The intense subsidence of the basin started with the Oligocene (Fig. 4).

The North Sea transgressed onto the lowlands of Belgium, the Netherlands, and Germany (Vinken et al., 1988; Zagwijn, 1989) and reworked the siliciclastic fluvial fill of the basin, provided from the heights of the Rhenish Massif in the South. During the Miocene, rich lignite seams of a total thickness of up to $100 \mathrm{~m}$ developed in the south-eastern part of the rift basin (Hager, 1986). They have been intensely mined for decades by the local lignite coal industry in open-cast mines.

The ingression of the Oligocene sea is well documented by subtidal to supratidal coastal marine deposits (Hilger, 1991; Petzelberger, 1994; Schäfer et al., 1996). The depositional pattern of the marine environments is characterized by a high-energy barrier beach and strand plain system. The coastal sands contain a rich variety of Ophiomorpha- and Scolithostype trace fossils (Petzelberger, 1994). Mollusc tests mostly are lost today as they were dissolved by humic acids from the lignite coal seams. The environmental interpretation focussed on the coastal deposits, as they are exposed in the open-cast mines. For this, measured columnar sections were taken (Hilger, 1991; Petzelberger, 1994). Farther towards land and only verified in wells, back-barrier muddy tidal environments developed; towards the sea, shelf deposits are displayed.

The North Sea regressed from Early Miocene onward (Boersma, 1991). As a consequence, a coastal plain spread out, covered by marshes, swamps, mires, and forests - the future lignite coal (Teichmüller, 1958 a, b, 1974, 1991; Mosbrugger et al., 1994; Figueiral et al., 1999). During the build-up of extensive swamps and bushlands in the Ville Formation, the coastal plain was frequently recovered by the sea, so that marginal marine sands repeatedly are intercalated with the peat (Petzelberger, 1994).

Due to the compaction of the accumulated organic masses and due to the structural subsidence of the rift basin from Pliocene onward, fluvial environments overran the swamps, mires, and bushlands (Hager et al., 1981; Hager, 1986; Hager \& Prüfert, 1988). Meandering and later on braided fluvial systems followed the stepwise regression of the sea (Boersma et al., 1981; Abraham, 1994; Valdivia-Manchego, 1994, 1996). The early river systems of the Meuse, Rhine, Sieg and Wupper frequently cut across the subsiding basin (Boenigk, 1981). At the end of Late Miocene and during the Pliocene, a gradual drop in temperature commenced that was documented by changes in the composition of plant communities (Mosbrugger \& Utescher, 1997; Utescher et al., 1997).

In the Middle Pleistocene, the Rhenish Massif was lifted to its present elevation (Fuchs et al., 1983; Meyer \& Stets, 1998). As a result, the Rhine River shed a thick gravel outwash-fan towards the North and formed the Main Terrace system (Boenigk, 1978, 1990, 1995 a, b; Schirmer, 1994).

\section{Lithofacies}

In addition to the sedimentological studies in opencast mines, the interpretation of depositional environments in lithological and geophysical well logs, contributed by the industry, was essential (Fig. 5).

The analogue well logs were all digitised to facilitate the visualisation and interpretation of depositional environments by modern data processing methods. Besides using classical log investigation methods, the sedimentological analysis was based on a multivariate

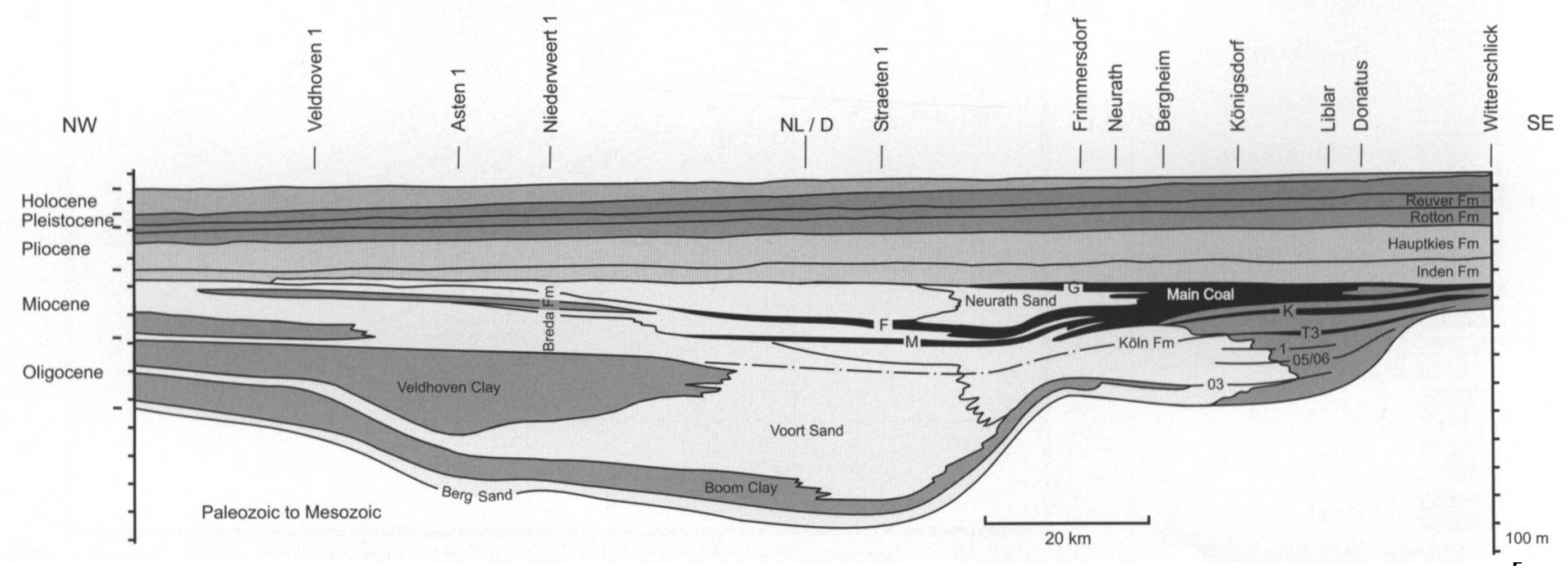

Fig. 4. Idealized section through the entire Lower Rhine Basin in the SE and the Rur Valley Graben in the NW. This section is a modified version from the one in the Atlas van Nederland (Deel 13: Geologie, fig. 45). It is completed with respect to the Pliocene and the Pleistocene by means of the wells Asten 1 and Straeten 1, and the position of the boundary Oligocene/Miocene in the Lower Rhine Basin is changed according to Schäfer et al. (in prep.). 

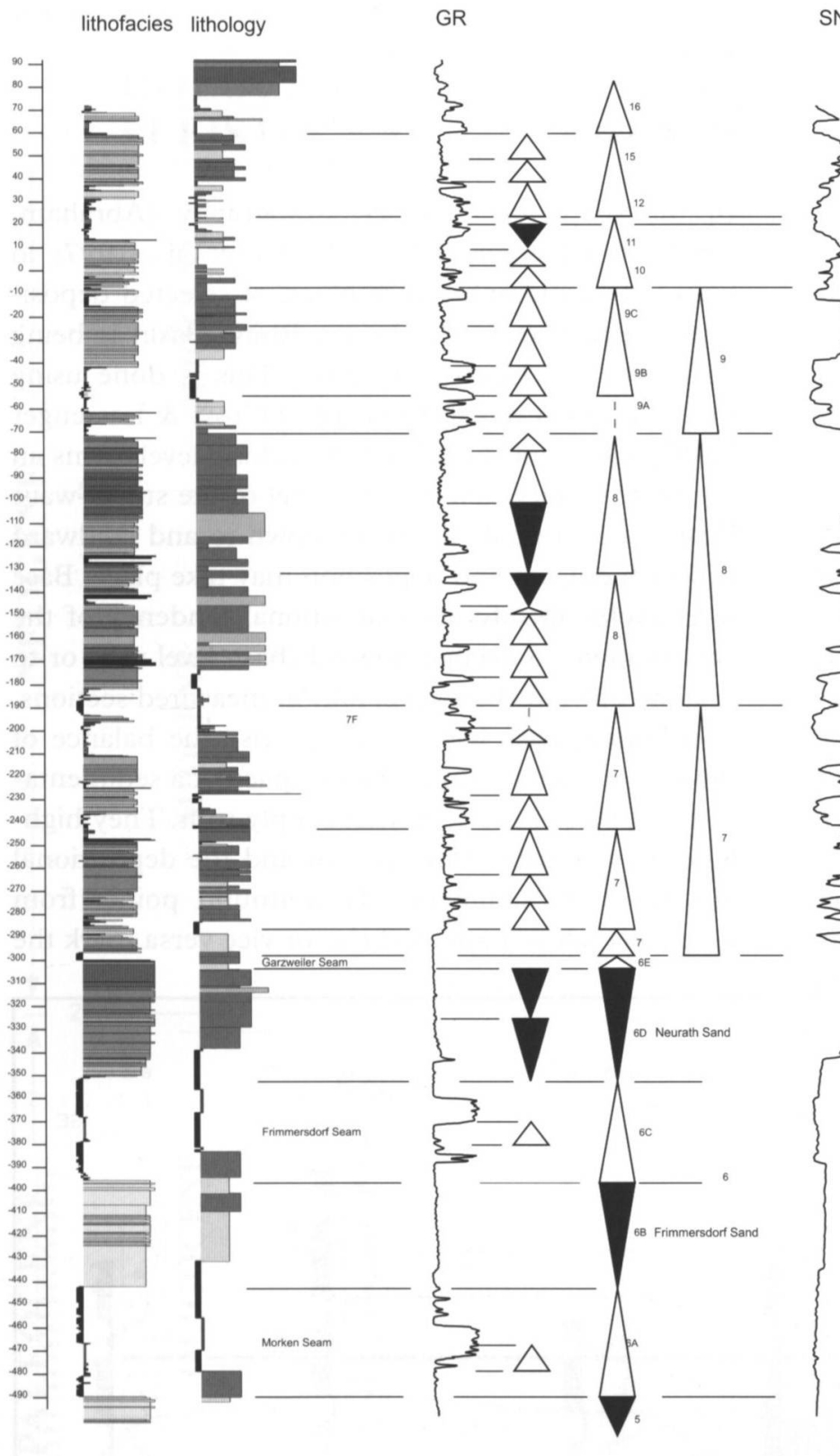

Fig. 5. The core of well SNQ 1 is described by its lithology log and by two geophysical logs (GR gamma ray, SN short normal resistivity). Both geophysical logs form the base for the calculation of the lithofacies $\log$ (Klett \& Schäfer, 1997; Klett, 2000) that permits the interpretation of the depositional environments. Base level cycles are symbolized by triangles, whereas 'base level fall' is in

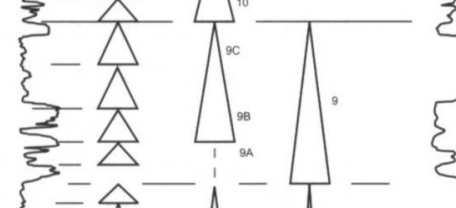
black and 'base level rise' in white notation.

GR

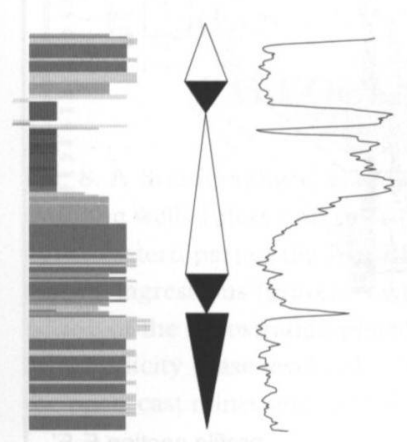

fluvial series

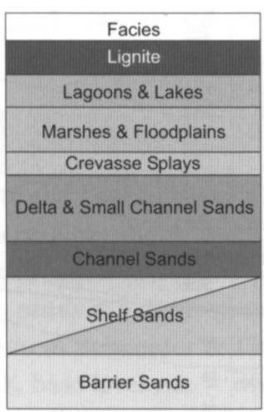

\section{Barrier Sands}

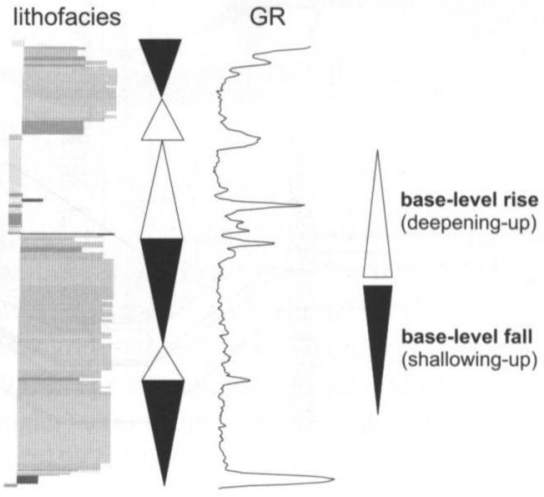

shallow marine series

Fig. 6. Two lithofacies logs of sedimentary sequences of a fluvial and a shallow marine series are shown (cf. Fig 5), together with the facies guide (centre) to address the depositional environments and sub-environments of the fluvial and shallow marine series. They are calculated from the geophysical well-logs (Klett \& Schäfer, 1997; Klett, 2000). For traditional well-log interpretation, gamma ray logs are also given. The triangle-diagrams depict base level cycles as they are used for facies interpretation sensu Cross \& Lessenger $(1997,1998)$ and Ramón \& Cross (1997). 
classification approach (Klett \& Schäfer, 1997). First, sedimentologically interpreted cores and outcrop sections were used to generate a database of characteristic log patterns. Second, the patterns of the geophysical well logs specified the 'electrofacies' (Serra, 1986), that are characteristic of the individual siliciclastic lithologies of the Lower Rhine Basin fill (Fig. 6).

Each 'electrofacies' of the geophysical logs was calculated with the distance concept of Mahalanobis (Klett, 2000) to specify the lithofacies of depositional environments ranging from shelf to alluvial environments. This method was optimised so that even subenvironments of the marginal marine and fluvial strata could be interpreted. Stratigraphic units could be defined and their correlation provided a lithostratigraphical framework for the entire basin.

A synthesis of the individual sedimentary architecture and the basin-fill episodes was elaborated. The biostratigraphic dating of the Cenozoic basin fill is still sparse up to now and only limited to areas close to the active open-cast mines (Utescher et al., 1997; Ashraf et al., 1995; 1997a, b; Huhn et al., 1997). Hence, the calculation of the lithofacies from electrical logs became a valuable stratigraphic tool to identi- fy and correlate the depositional environments in the Lower Rhine Basin (Fig. 7).

\section{Base Levels}

In the scope of sequence stratigraphy (Abraham, 1994; Petzelberger, 1994; Schäfer et al., 1997; in prep.), a stratigraphic correlation of selected depositional sequences in the Lower Rhine Basin is being developed (Eichhorst, in prep.). This is done using the base level cyclicity concept of Cross \& Lessenger (1997, 1998) (cf. Figs 5 and 6). A base level forms an idealized surface, fixed at the level of the storm-wave base of the coastal clinoform, down to and landward of which erosion and deposition may take place. Base level cycles specify the depositional tendency of the environment to deepen upward (base level rise) or to shallow upward (base level fall) in measured sections. In addition, base level cycles precise the balance of the ratio of the accommodation space of a sedimentary basin versus the sediment supply to it. They highlight its structural development and the depositional history of its sediments. Turn-around points from base level fall to base level rise or vice versa mark the

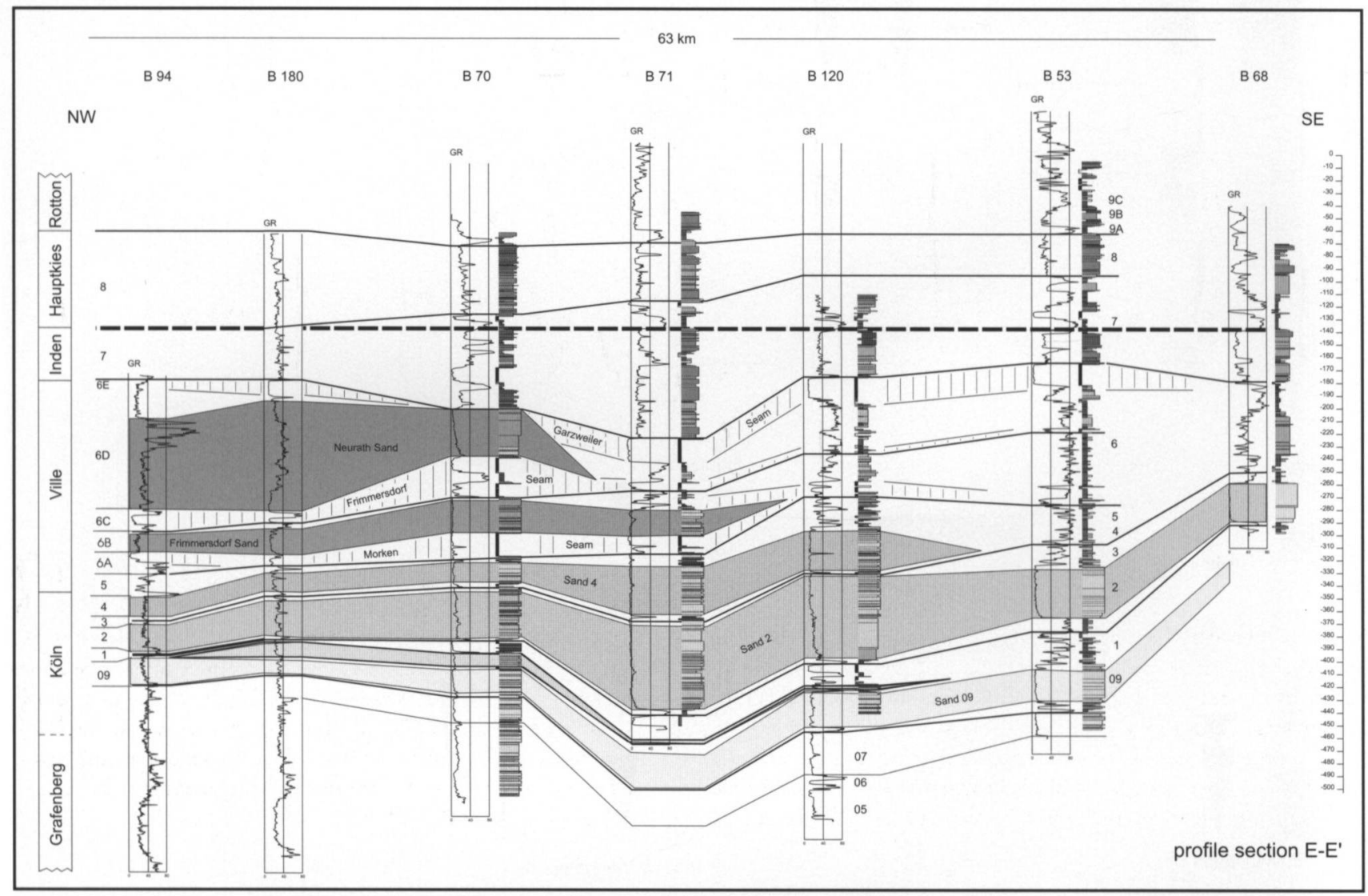

Fig. 7. A profile section, of $63 \mathrm{~km}$ in length, running NW-SE along the Erft Block from the south-eastern part of the Lower Rhine Basin to the south-eastern part of the Venlo Block (Klett, 2000). The section is compiled with calculated lithofacies logs and gamma-ray logs, respectively. Its stratigraphic extent is from the Oligocene Grafenberg Formation to the Rotton Formation. The datum line is formed by the base of the Hauptkies Formation. The section runs parallel to the western margin of the lignite main seam, where its subdivision by marine intercalations is evident. 


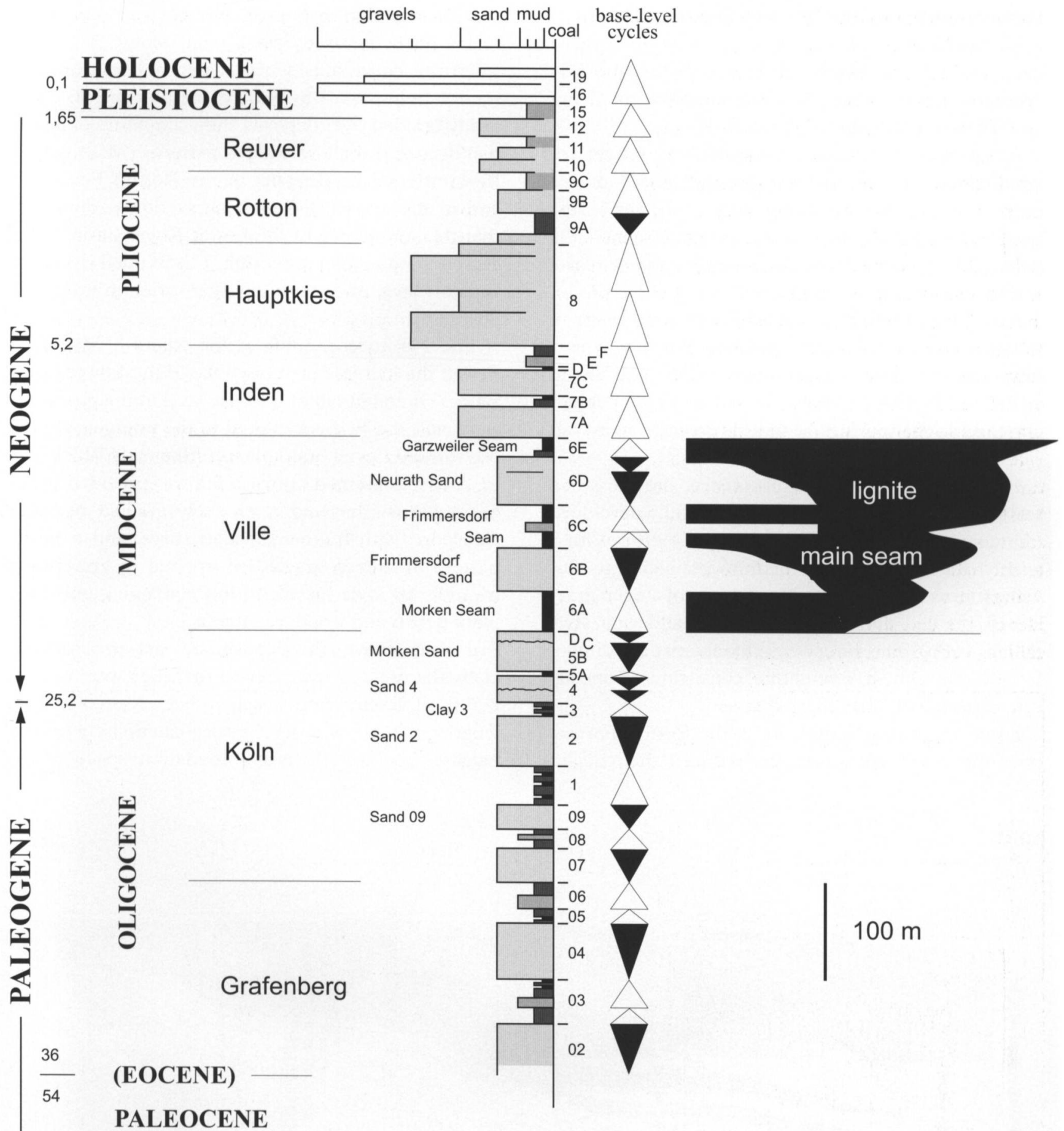

Fig. 8. A Stratigraphical Standard of the central Lower-Rhine Basin (to be localized in the centre of the Erft Block; cf. Fig. 3) is compiled from the wells Efferen on the southern Köln Block and SNQ 1 on the western Erft Block. The main lignite seam developed undisturbed only in the eastern part of the Erft Block. In other areas, it shows splitting into the seams Morken, Frimmersdorf, and Garzweiler, due to repeated marine ingressions (gravels $=$ white, sands $=$ light grey, mud $=$ dark grey, lignite $=$ black). Regional formation names are given, also the numbering of the lithostratigraphical code of Schneider $\&$ Thiele (1965). The stratigraphical standard of the basin fill is combined with the base level cyclicity (base level fall = black, base level rise $=$ white triangles) as is defined by environmental interpretations at measured sections in the open-cast mines and well profiles following Cross \& Lessenger $(1997,1998)$ and Ramón \& Cross $(1997)$.

position of time lines and serve as a basis for correlation within the sediment fill of the basin. The base level concept serves as a good small-scaled working tool for field study, and well profile analysis can be set in individual profiles (Fig. 8). The turn-around points fix transgressive surfaces resp. sequence boundaries as they are used in the sequence stratigraphy concept, even in sequences of a fifth to sixth order. 


\section{Depositional model of the Lower Rhine Basin}

The Lower-Rhine Basin was open towards the Tertiary North Sea, which reworked its sediments delivered from the Rhenish Massif (Fig. 9).

Coastal onlap caused the shoreline to retreat toward inland during the transgressive phase of the basin. With the maximum flooding of the sea - suspected to be little below the main lignite seam - the peat grew up during the highstand of the sea-level within a time span of $7.5 \mathrm{Ma}$ (Schäfer et al., in prep.). The consecutive phase of regression allowed rivers to follow, commencing with the Inden Formation in a high-sinuosity sandy meandering pattern (Abraham, 1994; Miall, 1996), with small amounts of pebbles enriched as channel lags, with little crevasse splay, but rich in oxbow lakes and plant remains.

Due to the rapid basin subsidence, the cross-bed sets of the Hauptkies Formation were fully developed (Abraham, 1994; Valdivia-Manchego, 1996). With a widely differing coarse to medium grain-size, its fluvial patterns resemble much a mixture of a deep gravel-bed braided and a gravel-sand meandering style (Miall, 1996). The Hauptkies characteristic sediment freight was almost monolithic consisting of mostly vein quartz, with little chert admixed.

Later on, during deposition of the Rotton Formation, the fluvial cross-bed sets reduced their height and became rich in erosion surfaces and organic remains such as fruits, seeds, and wood fragments, when the basin subsidence ceased and the uniform sand supply passed-by toward the North Sea. These sandy braided river deposits show a mixture of perennial deep and shallow braided patterns (Miall, 1996). Intermittent lake deposits in the Rotton Formation and in the overlying Reuverian section demonstrate that the subsidence of the Lower Rhine Basin slowly ceased, tending to a minimum. The braided rivers still kept the style of distal braid plains, rich in water discharge.

The Pleistocene uplift of the Rhenish Massif renewed the increase of subsidence of the Lower Rhine Basin. The rapid fall of the base level in the glacial periods and the rich water-shed in the interglacial periods formed fluvial braid plains of the early Rhine River. A coarse-grained outwash fan was provided showing a heterolithic and a diversely grained bed-load transport, with frequent discordances, and a fluvial pattern in a deep gravel-bed braided to gravel-sand meandering style (Miall, 1996), containing only little plant debris and wood fragments.

As was shown, the depositional patterns of especially the braided rivers reveal that they were considerably different from each other. Moreover, the lengths of their base level cycles exemplify a critical balance between the accommodation space of the

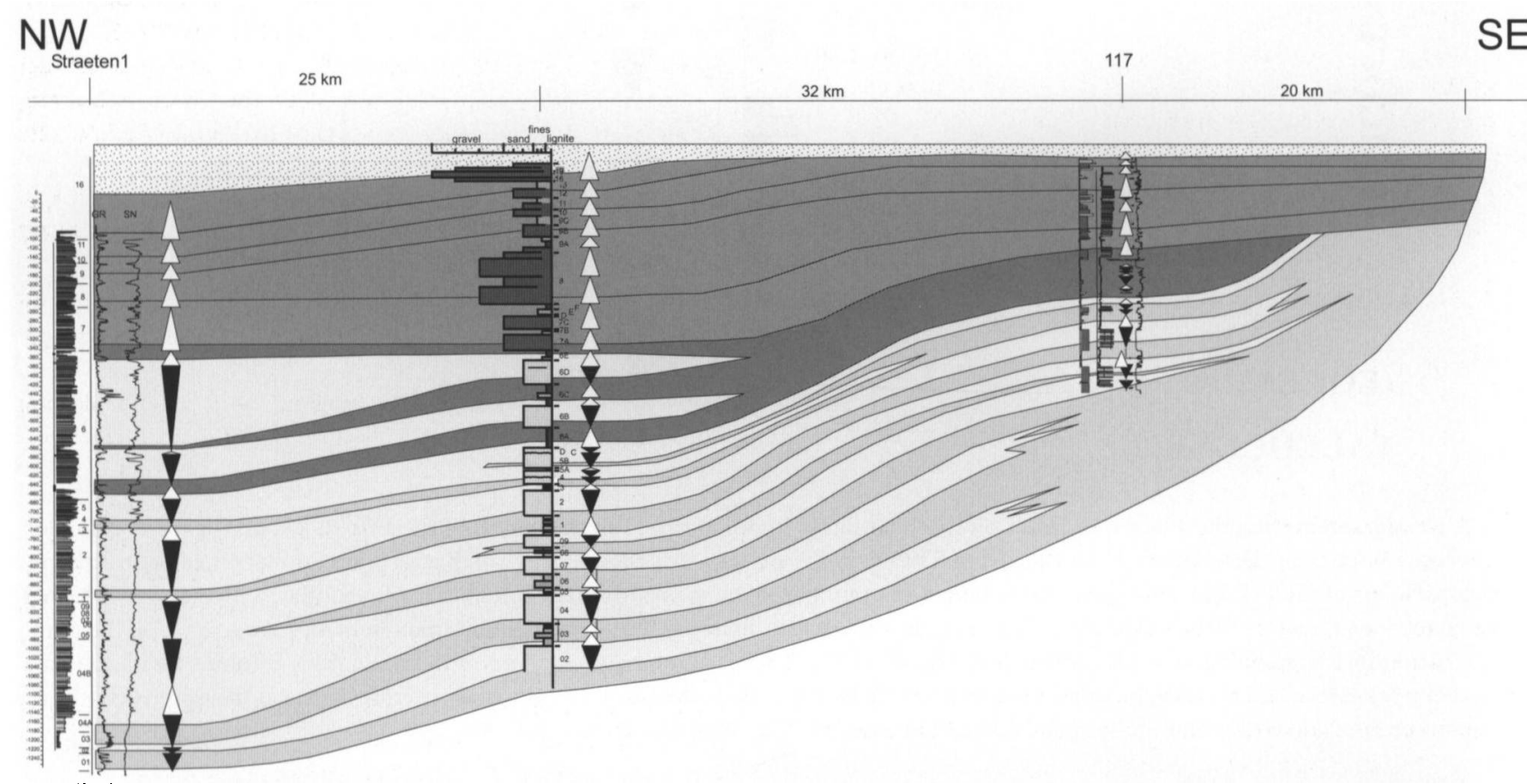

Fig. 9. Longitudinal section NW - SE parallel through the Lower Rhine Basin, combining well Straeten 1 in the distal and well 117 in the proximal reach of the basin. Straeten 1 shows a lithofacies log, which is calculated from its geophysical logs; the well 117 combines lithological and geophysical logs plus the calculated lithofacies log. Half way of the longitudinal section, the stratigraphical standard (cf. Fig. 8) is inserted. The long-distance correlation clarifies the development of the basal retrogradational (transgressive) shallow marine series, followed by an aggradational series forming the lignite, and terminated by a final progradational fluvial series. The base level cycles are used for the correlation of the well profiles (base level fall $=$ black, base level rise $=$ white triangles). 
basin versus its sediment supply (Ramón \& Cross, 1997). All rivers were perennial systems with a continuous water discharge all over the year. Their different fluvial patterns were preferably formed by the structural subsidence of the basin and the input of sediments from rich sources continuously uplifted in the Rhenish Massif and in more remote areas in the S and the SW. However, the meandering systems of the Inden Formation may have been modified by the compaction of the peats of the Ville Formation below, allowing channel abandonment and the formation of oxbow lakes.

\section{Acknowledgements}

We appreciate much the splendid help, which was given to us by Rheinbraun AG (Köln), Erftverband GmbH (Bergheim), Staatliches Umwelt-Amt Köln (Bonn) for providing the well data. The Deutsche Forschungsgemeinschaft gave financial support by a research grant under the auspices of the Sonderforschungsbereich SFB 350 (Bonn). Reinhard Gaupp (University of Jena) and Klaus Tietze (University of Marburg) improved an early draft of the manuscript thanks are due to them both.

\section{References}

Abraham, M., 1994. Untersuchungen zur sedimentologischen Entwicklung der fluviatilen Deckschichten (Miozän, Pliozän) der Rheinischen Braunkohle. Bonner Geowissenschaftliche Schriften 15: $227 \mathrm{pp}$.

Ashraf, A.R., Mosbrugger, V. \& Hebbeker, U., 1995. Palynologie und Palynostratigraphie des Neogens in der Niederrheinischen Bucht. Teil I: Sporen. Palaeontographica, Abt. B, 235: 61-73.

Ashraf, A.R., Mosbrugger, V. \& Utescher, T., 1997a. Palynological studies in the Neogene of the open pit mines Inden and Bergheim (Lower Rhine Embayment, Germany). Courier Forschungsinstitut Senckenberg 201: 29-46.

Ashraf, A.R., Utescher, T. \& Mosbrugger, V., 1997b. Tertiary palynostratigraphy: how reproducible are the results? Mededelingen Nederlands Instituut voor Toegepaste Geowetenschappen TNO 58: $163-170$.

Atlas van Nederland, 1985. Deel 13: Geologie. Staatsuitgeverij, 's Gravenhage: $23 \mathrm{pp}$.

Boenigk, W., 1978. Gliederung der altquartären Ablagerungen in der Niederrheinischen Bucht. Fortschritte in der Geologie von Rheinland und Westfalen 28: 135-212.

Boenigk, W., 1981. Die Gliederung der tertiären Braunkohlendeckschichten in derVille (Niederrheinische Bucht). Fortschritte in der Geologie von Rheinland und Westfalen 29: 193-263.

Boenigk, W., 1990. Die pleistozänen Rheinterrassen und deren Bedeutung für die Gliederung des Eiszeitalters in Mitteleuropa. In: Liedtke, H. (ed.): Eiszeitforschung. Darmstadt: 130-140

Boenigk, W., 1995a. Central Upland Margin Traverse. In: W. Schirmer (ed.): Quaternary Field Trips in Central Europe, 10, Pfeil (München): 559-598.

Boenigk, W., 1995b. Terrassenstratigraphie des Mittelpleistozän am Niederrhein und Mittelrhein. Mededelingen Rijks Geologische Dienst 52: 71-81.
Boersma, J.R., 1991. A large flood-tidal delta and its successive spill-over apron: Detailed proximal-distal facies relationships (Miocene Lignite Suite, Lower Rhine Embayment, Germany). In: Smith, G.D., Reinson, G.E., Zaitlin, B.A. \& Rahmani, R.A. (eds): Clastic Tidal Sedimentology. Canadian Society of Petroleum Geologists, Memoir 16: 227-254.

Boersma, J.R., De Gelder, A.V., Groot, T.D. \& Puigdefabregas, C., 1981. Formen fluviatiler Sedimentation in neogenen und jüngeren Ablagerungen im Braunkohlentagebau Frechen (Niederrheinische Bucht). Fortschritte in der Geologie von Rheinland und Westfalen 29: 275-307.

Cross, T.A. \& Lessenger, M.A., 1997. Correlation strategies for clastic wedges. In: Coulson, E.B., Osmond, J.C. \& Williams, F.T. (eds): Innovative Applications of Petroleum Technology in the Rocky Mountain Area. Rocky Mountain Association of Geologists: 183-203.

Cross, T.A. \& Lessenger, M.A., 1998: Sediment volume partitioning: rationale for stratigraphic model evaluation and high-resolution stratigraphic correlation. In: Gradstein, F.M., Sandvik, K.O. \& Milton, N.J. (eds): Sequence Stratigraphy - Concepts and Applications. Norwegian Petroleum Society (NPF), Spec. Publ. 8, Elsevier (Amsterdam): 171-195

Eichhorst, F. (in prep.). Zyklo-stratigraphischer Modellansatz für die Sedimentologie der tertiären Schichtenfolge in der Niederrheinischen Bucht. Dissertation University of Bonn (work title).

Figueiral, I., Mosbrugger, V., Rowe, N.P., Ashraf, A.R., Utescher, T. $\&$ Jones, T.P., 1999. The Miocene peat-forming vegetation of northwestern Germany: an analysis of wood remains and comparison with previous palynological interpretations. Revue Palaeobotany and Palynology 104: 239-266.

Fuchs, K., von Gehlen, K., Mälzer, H., Murawski, H. \& Semmel, A., (eds) 1983. Plateau Uplift. The Rhenish Shield - a case history. Springer (Berlin, Heidelberg, New York, Tokyo): 411 pp.

Hager, H., 1986. Peat accumulation and syngenetic clastic sedimentation in the Tertiary of the Lower Rhine Basin (F.R. Germany). Mémoire Societé Géologie de la France, N.S. 149: 51-56.

Hager, H., Kothen, H. \& Spann, R., 1981. Zur Setzung der Rheinischen Braunkohle und ihrer klastischen Begleitschichten. Fortschritte in der Geologie von Rheinland und Westfalen 29: 319-352.

Hager, H. \& Prüfert, J., 1988. Tertiär. In: Hilden, H.D. (ed.): Geologie am Niederrhein. $4^{\text {th }}$ ed., Geologisches Landesamt NRW (Krefeld): $32-40$.

Hilger, D., 1991: Zur Sedimentologie der Liegendschichten im Tagebau FORTUNA. Diploma thesis University of Bonn: 87 pp. (unpubl.)

Heumann, G. \& Litt, Th., 2002. Stratigraphy and palaeoecology of the Late Pliocene and Early Pleistocene in the open-cast mine Hambach (Lower Rhine Basin). Netherlands Journal of Geosciences / Geologie en Mijnbouw 81: 193-199 (this issue).

Huhn, B., Utescher, T., Ashraf, A.R. \& Mosbrugger, V., 1997. The peat-forming vegetation in the Middle Miocene Lower Rhine Embayment, an analysis based on palynological data. Mededelingen Nederlands Instituut voor Toegepaste Geowetenschappen TNO 58: 211-218.

Jentzsch, T. \& Siehl, A., 2002. Kinematic subsidence modelling of Lower Rhine Basin. Netherlands Journal of Geosciences / Geologie en Mijnbouw 81: 231-239 (this issue).

Klett, M., 2000. Sedimentologie des Tertiärs der Niederrheinischen Bucht - Interpretation anhand von Bohrungen und Bohrlochmessungen. Bonner Geowissenschaftliche Schriften 28, Dissertation University of Bonn: 133 pp.

Klett, M. \& Schäfer, A., 1997: Das Tertiär der Niederrheinischen Bucht - Interpretation der Sedimentfazies anhand von Bohrun- 
gen und Bohrlochmessungen. Zentralblatt Geologie-Paläontologie, Teil I, 1996: 443-456.

Meyer, W. \& Stets, J., 1998. Junge Tektonik im Rheinischen Schiefergebirge und ihre Quantifizierung. Zeitschrift der Deutschen Geologischen Gesellschaft 149: 359-379.

Miall, A.D., 1996. The Geology of Fluvial Deposits, Sedimentary Facies, Basin Analysis and Petroleum Geology. Springer (Berlin, Heidelberg, New York): 582 pp.

Mörs, T., 2002. Biostratigraphy and paleoecology of Tertiary vertebrates in the Lower Rhine Embayment (NW-Germany). Netherlands Journal of Geosciences / Geologie en Mijnbouw 81: 177183 (this issue).

Mosbrugger, V., Gee, C.T., Belz, G. \& Ashraf, A.R., 1994. Threedimensional reconstruction of an in-situ Miocene peat forest from the Lower Rhine Embayment, northwestern Germany new methods in palaeovegetation analysis. Palaeogeography, Palaeoclimatology, Palaeoecology 110:295-317.

Mosbrugger, V. \& Utescher, U., 1997. The coexistence approach a method for quantitative reconstructions of Tertiary terrestrial palaeoclimate data using plant fossils. Palaeogeography, Palaeoecology, Palaeoclimatology 134: 61-86.

Petzelberger, B., 1994. Die marinen Sande im Tertiär der südlichen Niederrheinischen Bucht - Sedimentologie, Fazies und stratigraphische Deutung unter Berücksichtigung der Sequenzstratigraphie. Bonner Geowissenschaftliche Schriften 14: 112 pp.

Ramón, J.C. \& Cross, T.A., 1997. Characterization and prediction of reservoir architecture and petrophysical properties in fluvial channel sandstones, middle Magdalena Basin, Colombia. CT\&F - Ciencia, Technología y Futuro 1: 19-46.

Schäfer, A., 1994: Die Niederrheinische Bucht im Tertiär Ablagerungs- und Lebensraum. In: Von Koenigswald, W. \& Meyer, W. (eds): Erdgeschichte im Rheinland. Fossilien und Gesteine aus 400 Millionen Jahren. Pfeil (München): 155-164.

Schäfer, A., Hilger, D., Gross, G. \& von der Hocht, F., 1996. Cyclic sedimentation in Tertiary Lower-Rhine Basin (Germany) - the 'Liegendrücken' of brown coal open-cast Fortuna mine. Sedimentary Geology 103: 229-247.

Schäfer, A., Utescher, T. \& Von der Hocht, F., 1997. Klastische Sedimentsysteme im Tertiär der Niederrheinischen Bucht.- In: Ricken, W. (ed.): Sediment '97, 12. Sedimentologentreffen, 21.24. Mai 1997 am Geologischen Institut der Universität zu Köln (Exkursion E 4); Terra Nostra 97/3, Alfred-Wegener-Stiftung (Köln): 68-113.

Schäfer, A., Utescher, T., Mörs, Th., (in prep.): The Cenozoic Lower Rhine Basin, W-Germany - stratigraphy of its basin-fill.

Schirmer, W., 1994. Der Mittelrhein im Blickpunkt der Rheingeschichte. In: Von Koenigswald, W. \& Meyer, W. (eds):
Erdgeschichte im Rheinland. Fossilien und Gesteine aus 400 Millionen Jahren. Pfeil (München): 179-188.

Schneider, H. \& Thiele, S., 1965. Geohydrologie des Erftgebietes. Ministerium für Ernährung, Landwirtschaft und Forsten, Nordrhein-Westfalen (Düsseldorf): $185 \mathrm{pp}$.

Serra, O., 1986. Fundamentals of Well-Log Interpretation. (2. The Interpretation of Logging Data). Developments in Petroleum Science $15 \mathrm{~B}$, Elsevier (Amsterdam): $684 \mathrm{pp}$.

Teichmüller, M., 1958a. Rekonstruktion verschiedener Moortypen des Hauptflözes der niederrheinischen Braunkohle. Fortschritte in der Geologie von Rheinland und Westfalen 2: 599-612.

Teichmüller, R., 1958b. Die Niederrheinische Braunkohlenformation - Stand der Untersuchungen und offene Fragen. Fortschritte in der Geologie von Rheinland und Westfalen 2: 721-750.

Teichmüller, R., 1974. Die tektonische Entwicklung der Niederrheinischen Bucht. In: Illies, J.H. \& Fuchs, K. (eds): Approaches to Taphrogenesis. Schweizerbart (Stuttgart): 269-285.

Teichmüller, M., 1991: Rekonstruktionen verschiedener Moortypen des Hauptflözes der niederrheinischen Braunkohle. Geologisches Landesamt Nordrhein-Westfalen (Krefeld): 31 pp.

Thomsen, A. \& Siehl, A., 2002. Towards a balanced 3D kinematic model of a faulted domain - the Bergheim open pit mine-. Netherlands Journal of Geosciences / Geologie en Mijnbouw 81: 241-250 (this issue).

Utescher, T., Gebka, M., Mosbrugger, V., Schilling, H.-D. \& Ashraf, A.R., 1997. Regional palaeontological-climatological palaeoclimate reconstruction of the Neogene Lower Rhine Embayment. Mededelingen Nederlands Instituut voor Toegepaste Geowetenschappen TNO 58: 263-271.

Utescher, T., Mosbrugger, V. \& Ashraf, A.R., 2002. Facies and paleogeography of the Tertiary of the Lower Rhine Embayment sedimentary versus climatic control-. Netherlands Journal of Geosciences / Geologie en Mijnbouw 81: 185-191 (this issue).

Valdivia-Manchego, M., 1994. Rechnergestützte stereophotogrammetrische Aufnahme und Auswertung fluviatiler Sedimentstrukturen im Tertiär der Niederrheinischen Bucht. Zentralblatt Geologie Paläontologie, Teil I, 1993: 1011-1026.

Valdivia-Manchego, M., 1996: Stereophotogrammetrisch-sedimentologische Aufnahme und 3D-Modellierung von Schrägschichtungsgefügen am Beispiel einer pliozänen fluvialen $\mathrm{Ab}-$ folge in der Niederrheinischen Bucht. Bonner Geowissenschaftliche Schriften 21: $152 \mathrm{pp}$.

Vinken, R. (ed.), 1988. The Northwest European Tertiary Basin. Geologisches Jahrbuch A100: 7-508.

Zagwijn, W.H., 1989. The Netherlands during the Tertiary and the Quaternary: A case history of coastal lowland evolution. Geologie en Mijnbouw 68: 107-120. 